\title{
TITLE:
}

\section{Intense Predation on Ascidians by a Trunk Fish, Ostracion immaculatus (Temminck et Schlegel) (Pisces: Ostraciidae)}

\section{$\operatorname{AUTHOR}(S)$ :}

Raveendran, T. V.; Harada, Eiji

\section{CITATION:}

Raveendran, T. V.... [et al]. Intense Predation on Ascidians by a Trunk Fish, Ostracion immaculatus (Temminck et Schlegel) (Pisces: Ostraciidae). PUBLICATIONS OF THE SETO MARINE BIOLOGICAL LABORATORY 1996, 37(1-2): 193-200

\section{ISSUE DATE:}

1996-02-29

URL:

http://hdl.handle.net/2433/176252

RIGHT: 


\title{
Intense Predation on Ascidians by a Trunk Fish, Ostracion immaculatus (Temminck et Schlegel) (Pisces : Ostraciidae)
}

\author{
T.V. RAVEENDRAN ${ }^{1)}$ and EIJI HARADA \\ Seto Marine Biological Laboratory, Kyoto University, Shirahama, Wakayama 649-22, Japan
}

\begin{abstract}
Intense predation on the ascidians Didemnum moseleyi, Polyclinum constellatum and Styela plicata by a trunk fish, Ostracion immaculatus, was demonstrated in laboratory feeding experiments. The finding of the remains of ascidians in the gut contents of newly captured fish from various localities in the vicinity of Shirahama, Japan, indicates that such predation is common in nature.
\end{abstract}

Key words : predation, ascidian, fish, Ostracion immaculatus, Didemnum moseleyi, Polyclinum constellatum, Styela plicata

\section{Introduction}

During the course of an investigation on temporal changes of the macrofouling communities on artificial substrata in Kanayama Bay near the Seto Marine Biological Laboratory, a remarkable difference in the abundance of attached compound ascidians between the sides of the panels was noticed by the first author (TVR). Since the panels were secured vertically in the sea back-to-back in pairs, about $1.5 \mathrm{~cm}$ apart, one side of each panel was fully exposed while the other side was comparatively protected. Immense growth of compound ascidians was often observed on the protected sides of the panels in apparent contrast to the fully exposed sides which were almost devoid of ascidians. Occasionally, a trunk fish, Ostracion immaculatus (Temminck et Schlegel, 1850), was observed feeding on the ascidians growing on the exposed sides of the panels. The protected sides were evidently inaccessible to the fish due to their large size.

Ascidians have widely been believed to be resistant to predation (see the review by Millar, 1971 ; Goodbody \& Gibson, 1974 ; Stoecker, 1978; Russ, 1980, 1982 ; Young \& Bingham, 1987 ; Lindquist et al., 1988 ; Davis \& Wright, 1989, 1990 ; Lindquist \& Fenical, 1991 ; Teo \& Ryland, 1995), partly due to the low intracellular $\mathrm{pH}$ in their tunic fluids and to their high vanadium content (Stoecker, 1980a, b, c). Increasing evidence suggests that ascidians, right from their larval to adult stages, are prone to predation from a variety of micro- and macro-predators such as crabs, echinoderms, molluscs and fishes (Millar, 1971; Parry, 1984 ; Briscoe \& Sebens, 1988; Osman et al., 1990 ; Stoner, 1990 ; Osman et al., 1992 ; Teo \& Ryland, 1994 ; Osman \& Whitlatch, 1995). Among these, molluscs are the most frequently recorded predators because of their slow and time consuming feeding process, and they are known to feed on a wide range of ascidians including those having vanadium and acids (Parry, 1984). On the other hand, the importance of fish predation on ascidians has been viewed as unclear (Teo \& Ryland, 1994). Most of the earlier reports on fishes feeding on ascidians are based on in situ field observations of their behaviour and on stomach content analysis. No direct evidence is available regarding the extent and intensity of predation by fish on ascidians.

The trunk fish, O. immaculatus, is common in the coastal waters of Shirahama in Wakayama, and is reported to be distributed widely in Japan, from northern Honshu to Shikoku (Nakabo, 1993). The present paper deals with predation by this fish on three ascidian

1) Home address: National Institute of Oceanography, Dona Paula, Goa 403 004, India. 
species, Didemnum moseleyi (Herdman, 1886), Polyclinum constellatum (Savigny, 1816) and Styela plicata (Lesueur, 1823), supported by laboratory experiments and gut content analysis.

\section{Materials and Methods}

All the fish and ascidians used in this investigation were collected from shallow coastal waters (less than $2.5 \mathrm{~m}$ deep) near Shirahama $\left(33^{\circ} 41^{\prime} \mathrm{N}, 135^{\circ} 21^{\prime} \mathrm{E}\right)$.

1. Feeding by the fish on three ascidian species (December 1994 to February 1995)

Two O. immaculatus (14 and $15 \mathrm{~cm}$ in standard length and 185 and $210 \mathrm{~g}$ in body weight, respectively), captured on 15 November 1994, were used in the preliminary experiments on feeding. The fish were kept in a tank of $65 \times 35 \times 50 \mathrm{~cm}$ with an ample supply of running sea water for nearly a month until they were used in the first experiment on 10 December. They were fed only on 1 to 3 -day old Artemia prior to the first experiment, but with small krill, flesh of pearl oyster Pinctada fucata and occasionally ascidians during the intervals between the experiments. No food other than ascidians was provided during the course of the experiments.

The ascidians growing on the protected side of fibre reinforced plastic (FRP) panels of $20 \times 20 \times$ $0.3 \mathrm{~cm}$, that had been suspended in the sea at Seto, Shirahama, were used for the experiments. The panels with colonies of D. moseleyi and P. constellatum and the individuals of $S$. plicata were retrieved respectively on 7 December 1994, 4 January 1995 and 24 February 1995, and were kept in running sea water in the laboratory for a few days prior to the experiment.

The experiment with $D$. moseleyi was initiated at 1200 hours on 10 December 1994 . Two panels with six colonies of this ascidian, covering $12,21,23,23,60$ and $107 \mathrm{~cm}^{2}$ respectively, were hung vertically in the experimental tank containing $O$. immaculatus. The tank was placed near a window and no artificial lighting was provided during the night hours. Sea water temperature recorded in the tank during the experiment varied between 16.0 and $18.8^{\circ} \mathrm{C}$.

Since the colonies of $D$. moseleyi (thickness up to about $0.6 \mathrm{~mm}$ ) grow two-dimensionally, the amount of the ascidian colonies consumed by the fish can be estimated from the area damaged. Therefore, the ascidian colonies were photographed on four occasions using a digital camera, i.e. just before transferring the panel into the experimental tank, after 7 hours at 1900 hours on the evening of the same day, after 3 days and after 7 days at 1200 hours. The photographs were processed using the Adobe Photoshop software on a Macintosh computer to measure the area covered by the ascidian colonies at each time; this was achieved by counting the number of dots falling on the image of the ascidian colonies and computing the area from it (one side of the panel had an area of $400 \mathrm{~cm}^{2}$, equivalent to 90,000 dots). The weight consumed by the fish was calculated from the weight of a known area of the colony.

The experiments with the other two ascidians were conducted in almost the same way, except that the amounts of these two ascidians consumed by the fish were calculated directly from the difference in their wet weights measured at the beginning and end of the experiment. No photographic technique mentioned above was used here. The experiment with P. constellatum was carried out from 22 to 26 January 1995, and sea water temperatures were between 14.2 and $16.0^{\circ} \mathrm{C}$. Two colonies growing on a panel were exposed to the same two $O$. immaculatus. The experiment with $S$. plicata was conducted from 1 to 20 March 1995, when the sea water temperature was between 13.6 and $15.8^{\circ} \mathrm{C}$. A panel with 49 individuals of this ascidian was exposed to the fish in the experimental tank.

\section{Feeding experiments with $P$. constellatum (November-December 1995)}

The experiments were carried out using ten freshly caught $O$. immaculatus. Three to four fish of similar size were selected for each experiment. After measuring the standard length and body weight, one fish was introduced into each experimental tank of $65 \times 35 \times 50 \mathrm{~cm}$ with an ample supply of running sea water and was kept without feeding for 24 hours prior to the experiment. Each experiment was performed for two to three days.

Fresh colonies of $P$. constellatum were tied onto FRP panels using rubber bands and a panel with 
an ascidian colony was suspended vertically in each tank containing the fish at 1700 hours on each day of the experiment. Three colonies were placed in control tanks without fish. The weight of each ascidian colony was measured just before introduction to the tanks, and at 0700 hours and 1700 hours on the following day, in order to investigate the feeding activity of the fish during night and day.

The first experiment was conducted from 27 November 1995 without warming the supplied sea water. Initially, it was intended to run the experiment for three days, but, because of sudden cold weather and a decrease in sea water temperature, one out of four fish died early in the morning of the third day and the condition of other fish deteriorated. Therefore, the sea water was kept at a constant temperature of $20^{\circ} \mathrm{C}$ for the next two experiments on 2 and 6 December 1995. In the third experiment in this series, the fish was provided with bryozoans (Watersipora subtorquata) and serpulids (Protohydroides elegans) as well as ascidians ( . constellatum) to clarify whether the fish exhibits any feeding preference. The resulted data from these experiments were subjected to two-way repeatedmeasures ANOVA.

\section{Gut contents examination (December 1995)}

O. immaculatus were collected from four localities in the vicinity of Shirahama. They were immediately fixed in alcohol, and their gut contents were subsequently examined under a microscope in the laboratory.

\section{Results}

1. Feeding by the fish on three ascidian species

Almost immediately after the introduction of the colonies of $D$. moseleyi into the tank, the fish started feeding on them, and they were nearly obliterated within 3 days (Fig. 1). The fish showed no signs of feeding on bryozoans and serpulids that were also present on the panel. No remains of ascidian colonies were observed on the floor of the tank. The calculated rate of consumption is $11.4 \mathrm{~g} / \mathrm{fish} /$ day or $0.6 \mathrm{~g} / 1 \mathrm{~g}$ fish/day during the first 7 hours and $1.8 \mathrm{~g} / \mathrm{fish} /$ day or $0.009 \mathrm{~g} / 1 \mathrm{~g}$ fish/day over a period of 3 days.

$P$. constellatum were almost completely consumed by the fish within 4 days. The calculated rate of consumption is $14.3 \mathrm{~g} / \mathrm{fish} /$ day or $0.07 \mathrm{~g} / 1 \mathrm{~g}$ fish/day. The fish did not cause apparent damage to $S$. plicata during the first week, but during the subsequent days the ascidians suffered considerable damage and the fish consumed all but one small individual within 20 days. The calculated rate of consumption is $13.3 \mathrm{~g} / \mathrm{fish} /$ day or $0.07 \mathrm{~g} / 1 \mathrm{~g}$ fish/day.

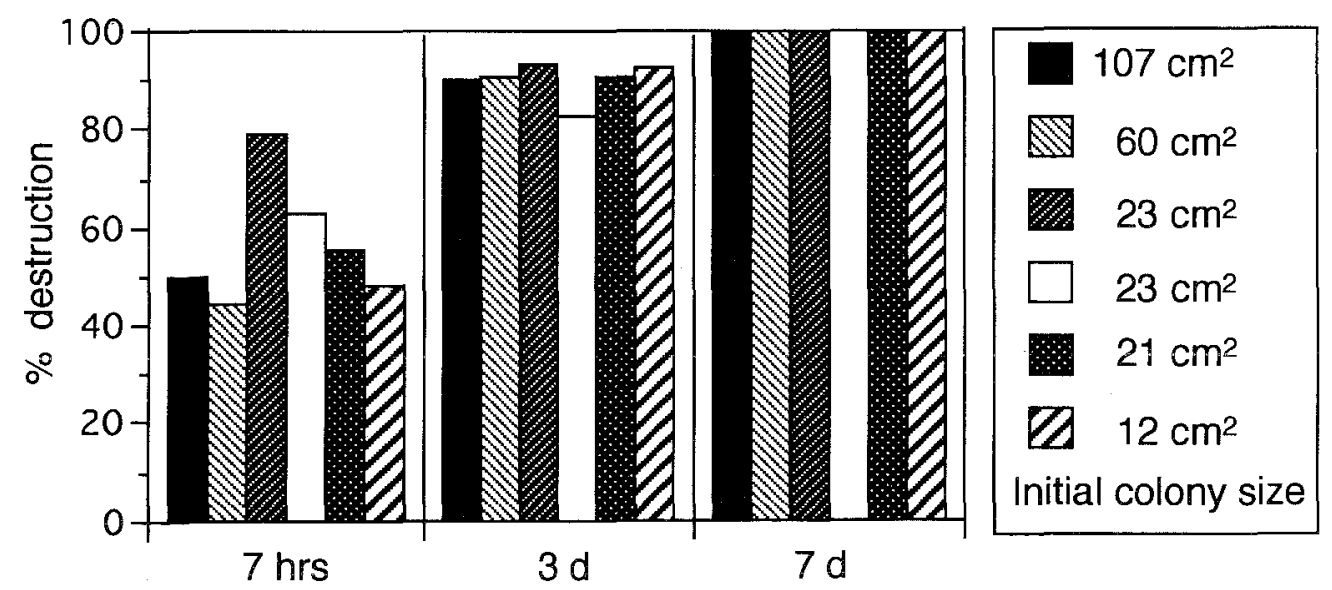

Fig. 1. Percentage destruction caused by $O$. immaculatus on colonies of $D$. moseleyi after 7 hours, 3 days and 7 days. 


\section{Feeding experiments with $P$. constellatum}

The results are presented in Tables 1-3. The fish were observed to feed on the ascidian in all three experiments. No significant changes were observed between the initial and the final body weight of the fishes (ANOVA, P>0.05). The initial weights of the ascidian colonies used showed no significant difference between the experimental and the control group (ANOVA, $\mathrm{P}>0.05$ ) in all experiments. On the contrary, a significant difference was detected in the weight loss of the ascidian between the two groups (ANOVA, $\mathrm{P}<0.05$ ), confirming that the fish fed on the ascidian in all three experiments.

The feeding experiments with $P$. constellatum revealed that the fish commonly feed on

Table 1. Amounts of $P$. constellatum eaten by $O$. immaculatus in the laboratory experiments at room temperature. A fresh ascidian colony was provided at $1700 \mathrm{hrs}$ each day.

\begin{tabular}{|c|c|c|c|c|c|c|c|}
\hline & \multicolumn{4}{|c|}{ O. immaculatus } & \multicolumn{3}{|c|}{ Control } \\
\hline & No. 1 & No. 2 & No. 3 & No. 4 & 1 & 2 & 3 \\
\hline \multicolumn{8}{|l|}{ Fish size } \\
\hline standard length $(\mathrm{cm})$ & 13.5 & 13.7 & 13.3 & 14.2 & & & \\
\hline initial weight $(\mathrm{g})$ & 173.0 & 171.0 & 173.0 & 184.0 & & & \\
\hline final weight $(\mathrm{g})$ & 177.0 & 173.0 & 175.0 & 186.0 & & & \\
\hline \multicolumn{8}{|l|}{ First day } \\
\hline initial weight of the ascidian (g) & 78.0 & 94.7 & 46.9 & 55.0 & 44.5 & 42.5 & 22.9 \\
\hline weight loss during $1700-0700 \mathrm{hrs}(\mathrm{g}$ ) & 0.9 & 1.2 & 0.9 & 0.1 & 0.0 & 1.0 & 0.9 \\
\hline weight loss during $0700-1700 \mathrm{hrs}(\mathrm{g})$ & 13.3 & 5.7 & 5.4 & 4.0 & 0.6 & 1.0 & 1.0 \\
\hline \multicolumn{8}{|l|}{ Second day } \\
\hline initial weight of the ascidian $(\mathrm{g})$ & 30.5 & 42.6 & 33.4 & 26.4 & 50.4 & 63.3 & 40.0 \\
\hline weight loss during $1700-0700 \mathrm{hrs}(\mathrm{g})$ & 1.0 & 0.1 & 1.1 & 0.1 & 0.0 & 0.0 & 0.0 \\
\hline weight loss during $0700-1700 \mathrm{hrs}(\mathrm{g})$ & 12.1 & 3.0 & 6.9 & 9.9 & 0.0 & 0.0 & 0.2 \\
\hline
\end{tabular}

Table 2. Amounts of $P$. constellatum eaten by $O$. immaculatus in the laboratory experiments at $20^{\circ} \mathrm{C}$. A fresh ascidian colony was provided at $1700 \mathrm{hrs}$ each day.

\begin{tabular}{|c|c|c|c|c|c|c|}
\hline & \multicolumn{3}{|c|}{ O. immaculatus } & \multicolumn{3}{|c|}{ Control } \\
\hline & No. 1 & No. 2 & No. 3 & 1 & 2 & 3 \\
\hline \multicolumn{7}{|l|}{ Fish size } \\
\hline standard length $(\mathrm{cm})$ & 12.0 & 11.0 & 11.0 & & & \\
\hline initial weight $(\mathrm{g})$ & 115.0 & 100.0 & 110.0 & & & \\
\hline final weight $(\mathrm{g})$ & 118.0 & 100.0 & 115.0 & & & \\
\hline \multicolumn{7}{|l|}{ First day } \\
\hline initial weight of the ascidian $(\mathrm{g})$ & 29.2 & 32.6 & 25.1 & 33.3 & 29.2 & 20.4 \\
\hline weight loss during $1700-0700 \mathrm{hrs}(\mathrm{g})$ & 0.1 & 0.6 & 0.2 & 0.0 & 0.7 & 0.5 \\
\hline weight loss during $0700-1700 \mathrm{hrs}(\mathrm{g})$ & 4.6 & 2.4 & 3.7 & 0.0 & 0.6 & 0.3 \\
\hline \multicolumn{7}{|l|}{ Second day } \\
\hline initial weight of the ascidian (g) & 33.1 & 24.0 & 29.3 & 20.8 & 19.3 & 17.7 \\
\hline weight loss during $1700-0700 \mathrm{hrs}(\mathrm{g})$ & 1.3 & 0.0 & 1.8 & 0.3 & 0.0 & 0.1 \\
\hline weight loss during $0700-1700 \mathrm{hrs}(\mathrm{g})$ & 6.1 & 4.5 & 0.0 & 0.0 & 0.5 & 0.6 \\
\hline \multicolumn{7}{|l|}{ Third day } \\
\hline initial weight of the ascidian (g) & 25.3 & 21.9 & 31.8 & 24.2 & 22.1 & 24.6 \\
\hline weight loss during $1700-0700 \mathrm{hrs}(\mathrm{g})$ & 3.7 & 1.4 & 6.3 & 0.8 & 0.3 & 1.4 \\
\hline weight loss during $0700-1700 \mathrm{hrs}(\mathrm{g})$ & 10.8 & 3.4 & 3.0 & 0.0 & 0.6 & 0.3 \\
\hline
\end{tabular}


Table 3. Amounts of $P$. constellatum eaten by $O$. immaculatus in the laboratory experiments in which $P$. constellatum was offered together with colonies of serpulids ( $P$. elegans) and bryozoans ( $W$. subtorquata), at $20^{\circ} \mathrm{C}$. Fresh food animals were provided at $1700 \mathrm{hrs}$ each day.

\begin{tabular}{|c|c|c|c|c|c|c|}
\hline & \multicolumn{3}{|c|}{ O. immaculatus } & \multicolumn{3}{|c|}{ Control } \\
\hline & No. 1 & No. 2 & No. 3 & 1 & 2 & 3 \\
\hline \multicolumn{7}{|l|}{ Fish size } \\
\hline standard length (cm) & 12.5 & 12.5 & 12.0 & & & \\
\hline initial weight $(\mathrm{g})$ & 135.0 & 140.0 & 120.0 & & & \\
\hline final weight $(\mathrm{g})$ & 135.0 & 140.0 & 118.0 & & & \\
\hline \multicolumn{7}{|l|}{ First day } \\
\hline Ascidian : initial weight (g) & 17.5 & 15.3 & 17.7 & 21.5 & 12.5 & 15.6 \\
\hline weight loss after $24 \mathrm{hrs}(\mathrm{g})$ & 1.2 & 10.5 & 13.0 & 0.1 & 0.0 & 0.6 \\
\hline \multirow{2}{*}{$\begin{aligned} \text { Serpulid } & \text { : initial weight }(\mathrm{g}) \\
& \text { weight loss after } 24 \mathrm{hrs}(\mathrm{g})\end{aligned}$} & 24.0 & 20.2 & 19.2 & 21.5 & 17.7 & 22.0 \\
\hline & 0.2 & 0.9 & 0.1 & 1.5 & 0.0 & 0.0 \\
\hline \multirow{2}{*}{$\begin{aligned} \text { Bryozoan } & \text { : initial weight }(\mathrm{g}) \\
& \text { weight loss after } 24 \mathrm{hrs}(\mathrm{g})\end{aligned}$} & 12.5 & 11.5 & 15.3 & 16.7 & 19.7 & 21.6 \\
\hline & 0.0 & 0.0 & 0.0 & 0.0 & 0.0 & 0.3 \\
\hline \multicolumn{7}{|l|}{ Second day } \\
\hline \multirow{2}{*}{$\begin{aligned} \text { Ascidian } & \text { : initial weight }(\mathrm{g}) \\
& \text { weight loss after } 24 \mathrm{hrs}(\mathrm{g})\end{aligned}$} & 33.5 & 28.9 & 37.9 & 15.9 & 25.4 & 30.0 \\
\hline & 12.9 & 20.0 & 10.9 & 0.4 & 1.2 & 0.5 \\
\hline \multirow{2}{*}{$\begin{aligned} \text { Serpulid } & \text { : initial weight }(\mathrm{g}) \\
& \text { weight loss after } 24 \mathrm{hrs}(\mathrm{g})\end{aligned}$} & 19.3 & 30.7 & 23.3 & 40.0 & 18.7 & 22.9 \\
\hline & 0.4 & 0.7 & 0.0 & 0.3 & 0.2 & 0.1 \\
\hline \multirow{2}{*}{$\begin{aligned} \text { Bryozoan } & \text { : initial weight }(\mathrm{g}) \\
& \text { weight loss after } 24 \mathrm{hrs}(\mathrm{g})\end{aligned}$} & 14.3 & 19.6 & 15.2 & 16.7 & 21.3 & 14.4 \\
\hline & 0.3 & 0.0 & 0.1 & 0.0 & 0.0 & 0.4 \\
\hline \multicolumn{7}{|l|}{ Third day } \\
\hline \multirow{2}{*}{$\begin{aligned} \text { Ascidian } & \text { : initial weight }(g) \\
& \text { weight loss after } 24 \mathrm{hrs}(\mathrm{g})\end{aligned}$} & 50.3 & 32.5 & 40.2 & 44.0 & 23.4 & 32.1 \\
\hline & 11.7 & 4.5 & 15.4 & 0.0 & 0.4 & 1.1 \\
\hline \multirow{2}{*}{$\begin{aligned} \text { Serpulid } & \text { initial weight }(\mathrm{g}) \\
& \text { weight loss after } 24 \mathrm{hrs}(\mathrm{g})\end{aligned}$} & 38.8 & 19.8 & 29.9 & 24.6 & 20.8 & 23.0 \\
\hline & 0.8 & 0.3 & 0.0 & 0.7 & 0.4 & 0.0 \\
\hline \multirow{2}{*}{$\begin{aligned} \text { Bryozoan } & \text { : initial weight }(\mathrm{g}) \\
& \text { weight loss after } 24 \mathrm{hrs}(\mathrm{g})\end{aligned}$} & 19.3 & 21.3 & 14.0 & 16.9 & 15.3 & 17.0 \\
\hline & 0.0 & 0.0 & 0.1 & 0.2 & 0.3 & 0.0 \\
\hline
\end{tabular}

ascidians only during daytime (Tables $1 \& 2$ ). The fish exhibited a significant variation in feeding between the first and second days in the first experiment (ANOVA, P<0.01). However, the variation between the days was not significant in the case of the second and third experiments (ANOVA, $\mathrm{P}>0.05$ ).

The serpulids and bryozoans used in the third experiment did not exhibit any significant variation either in the initial weight or in the weight loss between the experimental and the control group (ANOVA, $\mathrm{P}>0.05$ ), indicating that the fish did not cause any damage to them.

\section{Gut contents examination}

The results of the examination of gut contents of $O$. immaculatus are given in Table 4 . The presence of $D$. moseleyi in all the specimens examined is notable. In some, D. moseleyi and $P$. constellatum contributed the major part of the diet. In the specimens from Sakata, the serpulids represented the major component, together with $D$. moseleyi growing in between their tubes.

\section{Discussion}

The present study establishes the fact that $O$. immaculatus feed on ascidians quite intensively and preferentially. The ascidian is clearly shown to be preferred to serpulids and 
Table 4. Gut contents of $O$. immaculatus collected from different localities in the vicinity of Shirahama, Kii Peninsula, Japan.

\begin{tabular}{|c|c|c|c|c|c|c|c|c|c|c|c|c|}
\hline \multirow{2}{*}{$\begin{array}{l}\text { Locality } \\
\text { of } \\
\text { collection }\end{array}$} & \multirow[b]{2}{*}{ Date } & \multirow{2}{*}{$\begin{array}{l}\text { Standard } \\
\text { length } \\
(\mathrm{cm})\end{array}$} & \multirow{2}{*}{$\begin{array}{l}\text { Body } \\
\text { weight } \\
\text { (g) }\end{array}$} & \multirow{2}{*}{$\begin{array}{c}\text { Didemnum } \\
\text { moseleyi }\end{array}$} & \multicolumn{5}{|c|}{ Food organisms } & \multirow[b]{2}{*}{ Algae } & \multirow[b]{2}{*}{ Others } & \multirow[b]{2}{*}{ Major component } \\
\hline & & & & & $\begin{array}{l}\text { Polyclinum } \\
\text { constellatum }\end{array}$ & Serpulids & Amphipods & Sponges & Foraminiferans & & & \\
\hline Minabe & 02.12 .95 & 12.0 & 127.9 & + & - & - & + & - & + & + & bivalves, gastropods, detritus & D. moseleyi \\
\hline Minabe & 29.11 .95 & 13.0 & 145.0 & + & - & + & - & - & + & + & gastropods, detritus & \\
\hline Minabe & 09.12 .95 & 13.0 & 200.0 & + & + & + & + & + & + & + & bivalves, gastropods, detritus & \\
\hline Minabe & 02.12 .95 & 13.5 & 177.8 & + & - & + & + & + & + & + & bivalves, detritus & \\
\hline Minabe & 02.12 .95 & 13.5 & 178.7 & + & - & - & - & + & + & + & gastropods, detritus & \\
\hline Fukuro & 30.11 .95 & 8.0 & 45.5 & + & - & + & + & - & - & + & detritus & \\
\hline Fukuro & 30.11 .95 & 11.0 & 117.0 & + & - & + & + & - & + & + & $\begin{array}{l}\text { bryozoans, bivalves, barna- } \\
\text { cles, nereids, detritus }\end{array}$ & \\
\hline Sakata & 10.12 .95 & 15.0 & 250.0 & + & - & + & + & - & - & + & egg masses & serpulids with $D$. moseleyi \\
\hline Sakata & 05.12 .95 & 18.0 & 404.0 & + & - & + & + & - & - & + & & serpulids with $D$. moseleyi \\
\hline Seto & 10.12 .95 & 10.0 & 70.0 & + & + & + & + & - & + & + & & D. moseleyi \\
\hline Seto & 10.12 .95 & 11.0 & 73.0 & + & + & - & + & - & + & + & gastropods, nereids & P. constellatum \\
\hline
\end{tabular}


bryozoans. The feeding experiments with $P$. constellatum reveal that the fish commonly feed on the ascidian only during daytime. In earlier reports, the greater survival of ascidians on caged panels than on uncaged ones has been attributed to the avoidance of predation by fishes (Sutherland, 1974 ; Sutherland \& Karlson, 1977 ; Russ, 1980). However, the validity of these experiments was questioned because of the impact that cages themselves have on the community (Schmidt \& Warner, 1984 ; Stocker, 1986). The present study provides direct. proof for the predation by fish on ascidians.

Although the observed rates of consumption by the fish of the three ascidian species, $D$. moseleyi, $P$. constellatum and $S$. plicata, cannot be compared precisely because the conditions of the experiments were not identical, it appears that the fish feed on these ascidians nearly equally. More than $10 \mathrm{~g}$ of the ascidian, irrespective of the species, was consumed by the fish in a day. The severe damage caused by the fish to adult individuals of $S$. plicata is noteworthy. Sutherland (1974) reported that only young individuals of S. plicata were vulnerable to grazing fishes; the thick test of the adult was believed to have prevented predation. However, the present observation shows that even adult individuals of $S$. plicata are not completely resistant to predation from fishes. At the same time, the fact that the fish did not inflict much damage during the first week of the introduction of the ascidian may be taken as an indication that under normal circumstances, when there is an alternative food resource, the fish may not attempt to feed on this particular ascidian species.

O. immaculatus is considered to be omnivorous (Nakabo, 1993), and the examination of gut contents during the present study also showed the presence of a wide variety of food items. It is remarkable, however, that the ascidians, especially D. moseleyi, were invariably present in all the fish examined, irrespective of their locality of collection. Though serpulid polychaetes were found to contribute a major part of the diet in comparatively large fish collected from Sakata in the inner part of Tanabe Bay, they were accompanied by $D$. moseleyi which grew among their tubes. It is likely that the fish were actually feeding on $D$. moseleyi.

\section{Acknowledgements}

The authors wish to thank Dr. T. Nishikawa of Nagoya University for identifying the ascidians, Mr. R. Asai of our Laboratory for developing the computer program for measuring the area of the ascidian colonies, and Mr. H. Tanase, Mr. T. Yamamoto and Mr. M. Ohta for their assistance in catching the fish. The authors are particularly grateful to Dr. Y. Yusa for his advice and critical comments and to Prof. M. Nishihira of Tohoku University for critically reading the manuscript. The first author (TVR) is grateful to the Ministry of Science, Culture and Education, Japan for awarding a scholarship and to the Government of India for providing the opportunity to study in Japan.

\section{Literature Cited}

Briscoe, C.S. \& Sebens, K.P. 1988. Omnivory in Strongylocentrotus droebachiensis (Muller) (Echinodermata : Echinoidea) : predation on subtidal mussels. J. exp. mar. Biol. Ecol., 115: 124.

Davis, A.R. \& Wright, A.E. 1989. Interspecific differences in fouling of two congeneric ascidians (Eudistoma olivaceum and E. capsulatum): is surface acidity an effective defense? Mar. Biol., 102: 491-497.

Davis, A.R. \& Wright, A.E. 1990. Inhibition of larval settlement by natural products from the ascidian, Eudistoma olivaceum (Van Name). J. Chem. Ecol., 16: 1349-1357.

Goodbody, I. \& Gibson, J. 1974. The biology of Ascidia nigra (Savigny) V. Survival in populations settled at different times of the year. Biol. Bull., 146:217-237.

Lindquist, N. \& Fenical, W. 1991. Polyclinal, a new polyhydroxy benzaldehyde from the marine ascidian Polyclinum planum. Experientia, 47 : 503-504. 
Lindquist, N., Fenical, W., Van Duyne, G.D. \& Clardy, J. 1988. New alkaloids of the lamellarin class from the marine ascidian Didemnum chartaceum (Sluiter, 1909). J. Org. Chem., 53: 4570-4574.

Millar, R.H. 1971. The biology of ascidians. In: Russel, F.S. \& Yonge, M. (Eds.), Advances in Marine Biology, 9, pp. 1-100.

Nakabo, T. 1993. Fishes of Japan with pictorial keys to the species. Tokai University Press, p. 1474.

Osman, R.W. \& Whitlatch, R.B. 1995. Predation on early ontogenetic life stages and its effect on recruitment into a marine epifaunal community. Mar. Ecol. Prog. Ser., 117: 111-126.

Osman, R.W., Whitlatch, R.B. \& Malatesta, R.J. 1992. Potential role of micro-predators in determining recruitment into a marine community. Mar. Ecol. Prog. Ser., 83: 35-43.

Osman, R.W., Whitlatch, R.B., Malatesta, R.J. \& Zajac, R.N. 1990. Ontogenetic changes in trophic relationships and their effects on recruitment. In: Barnes, M. \& Gibson, R.N. (Eds.), Trophic Relationships in the Marine Environment, Proc. 24th European Mar. Biol. Symp., Aberdeen University Press, Scotland, pp. 117-129.

Parry, D.L. 1984. Chemical properties of the test of ascidians in relation to predation. Mar. Ecol. Prog. Ser., 17 : 279-282.

Russ, G.R. 1980. Effects of predation by fishes, competition, and structural complexity of the substratum on the establishment of a marine epifaunal community. J. exp. mar. Biol. Ecol., 42 : $55-69$.

Russ, G.R. 1982. Overgrowth in a marine epifaunal community : competitive hierarchies and competitive networks. Oecologia, $53: 12-19$.

Schmidt, G.H. \& Warner, G.F. 1984. Effects of caging on the development of a sessile epifaunal community. Mar. Ecol. Prog. Ser., 15: 251-263.

Stocker, L.J. 1986. Artifactual effects of caging on the recruitment and survivorship of a subtidal colonial invertebrate. Mar. Ecol. Prog. Ser., 34: 305-307.

Stoecker, D. 1978. Resistance of a tunicate to fouling. Biol. Bull., 155: 615-626.

Stoecker, D. 1980a. Distribution of acid and vanadium in Rhopalaea birkelandi Tokioka. J. exp. mar. Biol. Ecol., 48 : 277-281.

Stoecker, D. 1980b. Relationship between chemical defense and ecology in benthic ascidians. Mar. Ecol. Prog. Ser., 3: 257-265.

Stoecker, D. 1980c. Chemical defenses of ascidians against predators. Ecology, 61 : 1327-1334.

Stoner, D.S. 1990. Recruitment of a tropical colonial ascidian : relative importance of pre-settlement and post-settlement processes. Ecology, 71: 1682-1690.

Sutherland, J.P. 1974. Multiple stable points in natural communities. Am. Nat., 108: 859-873.

Sutherland, J.P. \& Karlson, R.H. 1977. Development and stability of the fouling community at Beaufort, North Carolina. Ecol. Monogr., 47: 425-446.

Teo, S.L.M. \& Ryland, J.S. 1994. Toxicity and palatability of some British ascidians. Mar. Biol., 120 : 297-303.

Teo, S.L.M. \& Ryland, J.S. 1995. Potential antifouling mechanisms using toxic chemicals in some British ascidians. J. exp. mar. Biol. Ecol., 188: 49-62.

Young, C.M. \& Bingham, B.L. 1987. Chemical defense and aposematic coloration in larvae of the ascidian Ecteinascidia turbinata. Mar. Biol., 96 : 539-544. 